chemistry and industrial applications of cellulose will be presented. The symposium will be divided into three sessions, at the first of which, on the chemistry of cellulose and its derivatives, the following topics will be discussed : recent advances in the chemistry of cellulose; an organic chemical approach to cellulose technology ; photo-degradation of cellulose ; the 'activation' of cellulose; and cellulose acetate. At the second session, on paper and pulp, sources of cellulose for paper-making will be considered, followed by reviews of recent trends in Scandinavian pulp research and pulp manufacture, and fundamental studies on the physical and chemical properties of fibres for paper-making. Finally, the industrial applications of cellulose and its derivatives will be considered (cellulose ethers and their applications; textile finishing ; packaging problems ; and coloured film). Lectures and discussions will be held during the mornings, with informal meetings, works visits and social events in the afternoons. The registration fee for the symposium is two guineas. Registration forms and further information can be obtained from the Assistant Secretary, Royel Institute of Chemistry, 30 Russell Square, London, W.C.1.

\section{Colonial Service : Recent Appointments}

THE following appointments have recently been made in the Colonial Service: H. H. Croucher (director of agriculture, British Guiana), director of agriculture, Western Region, Nigeria; J. H. M. McNaughton (senior geologist, Northern Rhodesia), director of Geological Survey, Nyasaland; W. G. C. Forsyth (senior scientific officer, Colonial Microbiological Research Institute), principal scientific officer, Colonial Microbiological Research Institute; G. H. S. Wood (assistant conservator of forests, Uganda), senior scientific officer (forest botanist), North Borneo; J. W. Macaulay (senior veterinary research officer, Kenya), chief veterinary research officer, Kenya; R. N. Sanders (senior veterinary officer, Uganda), deputy director of veterinary services and animal industry, Uganda; Dr. L. E. Arnold (assistant bacteriologist, Jamaica), bacteriologist, Jamaica; M. S. Brooks (clerk, Grade 1A, East African Railways and Harbours), statistician, East Africa High Commission; C. W. Hewitt (agricultural chemist, Jamaica), senior agricultural chemist, Jamaica ; W. P. Langridge (assistant field zoologist, Veterinary Department, Kenya), field zoologist, Veterinary Department, Kenya; D. H. Rhodes (fisheries officer, Uganda), senior fisheries officer, Uganda; D. C. M. Corbett, plant pathologist, Nyasaland ; D. L. Curtis, plant breeder (botanist), Nigeria ; E. C. W. Dunham, agricultural officer, Sierra Leone; K. M. Harris, entomologist, Nigeria; G. C. H. Hill and N. K. Dale-Jones, agricultural officers, Kenya ; T. E. O'Leary, agricultural officer, British Solomon Islands Protectorate; J. C. Phillips, agricultural officer, Uganda ; D. L. Stacey, agricultural officer, Federation of Malaya; G. G. Williams, agricultural officer, Nigeria; R. E. Wyatt, plant pathologist, Nigeria ; C. D. Burnside, surveyor, Nigeria ; E. A. Stephens, geologist, Sarawak, North Borneo and Brunei ; W. T. Dale, senior plant pathologist, West African Cacao Research Institute, Gold Coast; G. Fryer and T. D. Iles, scientific officers, Northern Rhodesia and Nyasaland Joint Fisheries Research Organization; J. Roffey, scientific officer (entomologist), East Africa High Commission; P. S. E. R. Dickens, veterinary officer, Uganda; M. B. Jacob and J. Prydie, veterinary officers, Kenya; I.
McLaughlan, veterinary officer, Nyasaland; J. A. R. Blacking, assistant adviser on aborigines, Federation of Malaya ; J. Bolton, chemist, Department of Science and Agriculture, Barbados; B. J. L. De Souza, D. E. Greenwood and D. W. T. Pedder, assistant conservators of forests, Northern Rhodesia; R. H. Kemp, assistant conservator of forests, Nigeria ; A. W. S. Mould and M. F. Purnell, soil survey officers, Gold Coøst; N. R. Quill, development officer, Agricultural Department, Somaliland Protectorate.

\section{Announcements}

THE Gold Medal of the Royal Astronomical Society has been awarded to Dr. Walter W. Barde, of the Mount Wilson Observatory, California, for his observational work on galactic and extra-galactic objects.

THE following appointments with effect from October 1 have been made in the Queen's University of Belfast : Dr. Alwyn Williams, lecturer in geology in the University of Glasgow, to the chrir of geology; Dr. John Heslop Harrison, reader in botany in University College, London, to the chair of botany.

Mr. H. FAULKNER, who has recently retired from the General Post Office with the rank of deputy engineer-in-chief, has been appointed director of the Telecommunication Engineering and Manufacturing Association. Mr. Faulkner has had a life-Iong connexion with telecommunications, having served for forty years with the Post Office; he has also been chairman of the South Midland Centre of the Institution of Electrical Engineers and, until recently, was a member of the council of that body.

Applications are invited for the Helen Putnam Fellowship for advanced research, a postdoctoral resident fellowship for women, with research facilities at Harvard University. The research may be in any field related to human genetics or mental health, including psychology, child development and other fields of social science. The stipend will be 3,000 dollars a year, with possibility of renewal. Application forms, to be returned by April 1, and further information can be obtained from the Secretary of the Graduate School, Radcliffe College, Cambridge 38, Massachusetts.

THE Medical Research Council is offering a number of fellowships in clinical research, tenable in the United Kingdom during the academic year 1954-55, which are open to suitably qualified medical graduates who desire to prepare themselves for a career in clinical research. The fellowships will be awarded for one year in the first instance, renewable annually up to a maximum of three years, and will carry a stipend of $£ 850$ a year, plus superannuation, with

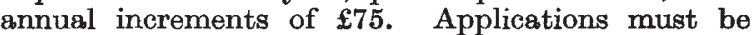
sponsored in each case by the head of the appropriate department in the candidate's university or medical school. Application forms can be obtained from the Secretary, Medical Research Council, 38 Old Queen. Street, London, S.W.1, to whom they must be returned not later than March 1 .

THE first and second parts of the fifth volume of Ambix, the journal of the Society for the Study of Alchemy and Early Chemistry, were published in October. They include a study by H. E. Stapleton of some previously unexplained features in the writings attributed to Jabir, an article by F. S. Taylor on the alchemist Hunyades, and several reviews. 